English texts. - D. A. Trotter (toim.), Multilingualism in later medieval Britain s. 77-92. Cambridge: D. S. Brewer.

2002: Mixed-language texts as data and evidence in English historical linguistics. - Donka Minkova \& Robert P. Stockwell (toim.), Studies in the history of the English language. A millenial perspective s. 51-78. TiEL 39. Berlin: Mouton de Gruyter.

Schendl, Herbert - Wright, Laura 2011: Code-switching in Early English. Historical background and methodological and theoretical issues. - Herbert Schendl \& Laura Wright (toim.), Codeswitching in Early English s. 15-46. TiEL 76. Berlin: Mouton de Gruyter.

SeBbA, MARK 2012: Researching and theorising multilingual texts. - Mark Sebba, Shahrzad Mahootian \& Carla Jonsson (toim.), Language mixing and codeswitching in writing s. 1-26. New York: Routledge.

SKH I = Suomen kulttuurihistoria 1. Taivas ja maa. Tuomas M. S. Lehtonen \& Timo Joutsivuo (toim.). Helsinki: Tammi 2002. Uusitalo, Harri 2019: Tausta, tekijä ja kieli. Filologinen tutkimus Aitolahden koodeksin lainsuomennoksesta. Turun yliopiston julkaisuja, Scripta Lingua Fennica Edita C 471. Turku: Grano Oy.

Wenzel, Siegfried 1994: Macaronic sermons. Bilingualism and preaching in late-medieval England. Michigan: The University of Michigan Press.

Wright, LAURA 1992: Macaronic writing in a London archive, 1380-1480. - Matti Rissanen, Ossi Ihalainen, Terttu Nevalainen \& Irma Taavitsainen (toim.), History on Englishes. New methods and interpretations in historical linguistics s. 762-77o. TiEL 10. Berlin: Mouton de Gruyter.

2000: Bills, accounts, inventories. Everyday trilingual activities in the business world of later medieval England. - D. A. Trotter (toim.), Multilingualism in later medieval Britain s. 149-156. Cambridge: D. S. Brewer

2011: On variation in medieval mixed language business writing. - Herbert Schendl \& Laura Wright (toim.), Codeswitching in Early English s. 191-218. TiEL 76. Berlin: Mouton de Gruyter.

\title{
Havaintoja lyhentämiskäytänteistä eräissä 1500-luvun suomalaisissa käsikirjoitusteksteissä
}

$\mathbf{y}$

Kuten tunnettua vanhimmassa kirjoitetussa suomen kielessä esiintyy runsaasti erityyppisiä vaikutteita vieraista kielistä. Yksi vähän tutkittu mutta merkittävä vierasvaikute on kirjoitustapaan omaksutut lukuisat lyhentämiskäytänteet ja etenkin latinasta lainatut lyhenteet (esim. etc.). Tässä kirjoituksessa selvitän eräiden vanhinta dokumentoitua suomea edustavien 1500-luvun käsikirjoitusten pohjalta, millaisia suomen kielen varhaiset lyhentämiskäytänteet ja lyhenteet olivat.
Lisäksi avaan lyhenteitä nykymerkein ja kontekstualisoin lyhentämiskäytänteet suhteessa latinan ja osin myös ruotsin vastaavan aikaisiin käytänteisiin. Aineistonani on joukko vanhimpia suomenkielisiä käsikirjoituksia: Kangasalan missalen suomenkielinen messu (KMM), Westhin koodeksi, Uppsalan käsikirja (UKK) ja Uppsalan evankeliumikirjan katkelma (UEK). Nämä käsikirjoitukset sisältävät liturgisia ja hengellisiä tekstejä, ja niitä pidetään niin sanotusti esiagricolalai- 
sina käsikirjoituksina; toisin sanoen tekstit on kirjoitettu ennen Mikael Agricolan vuonna 1549 painettujen liturgisten teosten ilmestymistä. ${ }^{1}$

Tarkastelemistani teksteistä Kangasalan missalen suomenkielinen messu on Kangasalan seurakunnalle kuuluneen Missale Aboensen loppuun lisätyille lehdille kirjoitettu jumalanpalvelusaineistoa sisältävä tekstikokonaisuus. Tekstit on ajoitettu 1540-luvun alkupuolelle (Häkkinen \& Tuppurainen 2014). Westhin koodeksi, joka sisältää kirkkokäsikirjan, messuaineistoa ja sielunhoito-oppaan, on kirjoitettu suurimmaksi osaksi vuosina 1545-1549, mutta osa teksteistä näyttää olevan kopioitu vanhemmista lähteistä (Häkkinen toim. 2012: 9-10). Uppsalan käsikirja, joka on messun sisältävä kirkkokäsikirja, on ajoitettu 1500-luvun puoliväliin (Walta 2017a). Uppsalan evankeliumikirjan katkelma, jossa on Raamatun tekstejä, on ajoitettu vuosien 1541-1544 välille ja sitä pidetään vanhimpana säilyneenä suomenkielisenä tekstinä (Walta 2017b; Häkkinen 2016: 138165). Näiden lisäksi olen silmäillyt läpi 150o-luvun jälkipuoliskolle ajoitetun Tammelan gradualen suomenkieliset osat sekä 1500-luvun lopulle ajoitetusta Tukholman suomalaisen seurakunnan luterilaisesta gradualesta tehdyn litteraation (Häkkinen \& Hannikainen 2013); mainitut tekstit eivät kuitenkaan tarjoa lyhenteiden osalta olennaista lisämateriaalia.

Käsikirjoituslähteeni ovat aikansa oppineiden käyttöön kirjoitettuja tekstejä. Ne liittyvät siihen historialliseen kehitykseen, jossa reformaation myötä kansankielestä tuli jumalanpalvelusten ja kirkollisten toimitusten kieli. Painettujen suomenkielisten tekstien puuttuessa papit

1. Kiitän Maria Kalliota kirjallisuusvinkeistä sekä pohdinnoista muutamien tekstissä esitettyjen lyhennetulkintojen parissa. Kiitän myös Virittäjän anonyymejä arvioijia sekä Kirsi-Maria Nummilaa heidän kommenteistaan. saattoivat käyttää kirkollisissa toimituksissa apunaan käsikirjoituksia.

Keskityn kirjoituksessani käsikirjoitusten suomenkielisiin osiin. Olen ottanut mukaan joitakin suomenkielisten virkkeiden keskellä olevia latinankielisiksi tulkittavia lyhenteitä, mutta kokonaan latinankielisten jaksojen lyhenteet olen jättänyt tarkastelun ulkopuolelle. En myöskään käsittele suomenkielisten tekstien latinankielisten otsikoiden lyhenteitä.

Käsikirjoitusaineistosta on olemassa aiempaa tutkimusta, ja siitä on julkaistu myös tieteellisiä editioita. Käsikirjoituksia on litteroitu, kuvailtu ja kommentoitu useissa lähteissä. (Ks. esim. Häkkinen toim. 2012 ja SKMI.) Näiden käsikirjoitusten tutkimuksen yhteydessä on tarkasteltu myös teksteissä esiintyviä lyhenteitä mutta vain suhteellisen pintapuolisesti keskittyen toisaalta yleisimpiin lyhenteisiin, toisaalta muutamiin erikoisuuksiin. Tarkastelemani editiot eivät ole aina yksimielisiä tekstin tulkinnoista, joten "oikean" näkemyksen muodostaminen pelkästään editioiden pohjalta on haastavaa. Tutkijan onkin - Marko Lambergia (2009: 365) lainatakseni - "perehdyttävä kirjoituksen ja kirjantuotannon kehitykseen, sillä pelkkiin editioihin luottava tutkija jää kollegojensa arviointien varaan".

Esittelen seuraavaksi lyhyesti käsikirjoitustutkimuksen ja lyhentämisen keskeistä käsitteistöä sekä lyhentämisen juuria. Tämän jälkeen analysoin aineistossani ilmeneviä lyhentämiskäytänteitä. Viimeisessä luvussa kokoan havaintoni ja esittelen muutamia jatkotutkimusaiheita.

\section{Käsitteistöä ja lyhentämis- käytänteiden taustaa}

Suomenkielisiä käsikirjoituksia koskevaa paleografista eli kirjoittamista, kirjoitusmerkkien kehitystä, kirjoitusvälineitä ja kirjoittamisen käytäntöjä tutkivaa kirjallisuutta on saatavilla vain vähän. Myöskään alan termistö ei ole täysin vakiintunutta. 
Paleografinen tutkimus on Suomessa pitkään keskittynyt vieraskielisiin, lähinnä latinan- tai ruotsinkielisiin, käsikirjoituksiin. Niinpä sen käsitteistökin on lainattu vieraskielisiä käsikirjoituksia koskevasta paleografisesta kirjallisuudesta. Muiden muassa Lamberg (2009: 368-369) käyttää latinalaista paleografiaa käsittelevässä artikkelissaan latinaan perustuvaa termistöä.

Tarkastelemani aiheen kannalta keskeiselle käsitteelle lyhennemerkki annetaan Tekstuaalitieteiden sanastossa (s.v. lyhennemerkki) seuraava yleisluontoinen määritelmä:

Antiikin ja keskiajan käsikirjoituksissa käytetyn lyhennejärjestelmän mukainen merkintä, joissa [sic!] sana typistetään jättämällä osa kirjaimista kirjoittamatta tai korvaamalla kirjaimia, merkkiryhmä tai sana erikoismerkillä. Kirjainten puuttuminen merkitään usein erilaisin sanan yläpuolelle tehdyin merkein tai kirjoittamalla sanan taivutusmuodon määrittämisen kannalta tarvittavat viimeiset kirjaimet yläindeksiksi. Nykykirjaimistossa yhä käytössä oleva keskiaikainen lyhennemerkki on \&-merkki.

Tästä määritelmästä poiketen käytän tekstissäni yksittäisistä merkeistä nimityksiä lyhennemerkki ja merkki; useamman merkin kokonaisuuksista käytän puolestaan nimityksiä lyhennemerkintä tai pelkkä merkintä.

Vanhimman kirjoitetun suomen kielen lyhentämiskäytänteillä oli esikuvansa vieraissa kielissä ja perustansa keskiajan ja antiikin käsikirjoituksissa. Antiikin Roomassa oli käytössä kolme lyhentämissysteemiä: notae juris tai notae antiquae, jota käytettiin etenkin oikeudellisissa asiakirjoissa, tironinen notae, joka on saanut nimensä Ciceron kirjurin Tiron mukaan, ja nomina sacra eli pyhien nimien lyhentämissysteemi, jonka kristityt lainasivat heprean kielen käytänteistä. Lyhenteitä käytettiin etenkin ajan säästämiseksi eli kirjoittamisen nopeuttamiseksi. Lyhentämiskäytänteet periytyivät myöhempään latinan kieleen, jossa merkintätavat kehittyivät ja käytettyjen lyhenteiden määrä kasvoi. Keskiajalla runsasta lyhenteiden käyttöä motivoi etenkin kirjoitusmateriaalien kalleus - lyhenteillä voitiin säästää tilaa. Latinan systeemi omaksuttiin kansankieliin, joissa lyhenteiden määrä jäi yleensä vähäisemmäksi kuin latinassa. (Ks. esim. Bischoff 2013: 150-156.) Latinan lyhentämiskäytänteitä omaksuttiin myös suomen kielen kirjoittamiseen. Vanhimmissa suomenkielisissä käsikirjoituksissa tavataan erilaisia lyhenteitä vaihtelevasti. Latinasta lyhentämiskäytänteet ovat olleet tuttuja käsikirjoitusten kirjoittajille ja käyttäjille, joiden koulutukseen on kuulunut ainakin jonkin verran latinan opintoja.

Koska käsikirjoitusten lyhentämiskäytänteet juontuvat latinan kirjoitustavoista, esittelen aineistoni lyhenteitä pääasiassa keskiaikaisen latinan lyhentämistä käsittelevän kirjallisuuden pohjalta. Latinan käytänteitä esittelen kuitenkin vain niiltä osin kuin niiden vaikutus näkyy aineistossani.

Lyhenteistä (lat. abbreviatio, engl. abbreviation) on tapana erotella ainakin suspensiolyhenteet (engl. suspensions; esim. latinankielisen sanan imperator lyhenteenä IMP.) ja kontraktiolyhenteet (engl. contractions; esim. latinankielisen sanan deus lyhenteenä $d \bar{s}$; ks. esim. Cappelli 1982 [1899]). Suspensiolyhenteet vastaavat lähinnä nykysuomen loppulyhenteiksi nimettyä lyhennetyyppiä (esim. sanan tunti lyhenteenä $t$ ) ja kontraktiolyhenteet lähinnä nykysuomen sisälyhenteitä (esim. sanan kerros lyhenteenä krs) (vrt. KO s. 143). Vanhojen tekstien lyhenteitä kuvaava tyypittely ei kuitenkaan vastaa täysin nykysuomen lyhennetyyppejä, eivätkä näihin tyypittelyihin kuuluvat nimitykset näin ollen ole keskenään synonyymisia. Käytänkin keskiajan ja uuden ajan taitteen aikai- 
sista lyhennetyypeistä tässä erikseen esittelemiäni nimityksiä.

Sekä suspensioissa että kontraktioissa on tyypillisesti käytetty jotakin merkkiä osoittamassa, että yksi tai useampia kirjaimia on jätetty pois (Clemens \& Graham 2007: 90). Sen lisäksi, että Cappelli (1982 [1899]) ja häntä seuraten muiden muassa Lamberg (2009: 368-369) jakavat lyhenteet suspensioihin ja kontraktioihin, he erottelevat neljä muuta ryhmää: pysyvämerkityksiset lyhennemerkit (esim. latinassa arabialaista numeroa 9 muistuttava merkki us-päätteen merkkinä), vaihtelevamerkityksiset lyhennemerkit (esim. latinassa puolipiste: lyhenne quib; on qui$b u s^{2}$ ja lyhenne $u i$; on uidelicet), kirjainten ylle sijoitetut kirjaimet (esim. latinassa $a^{a}$ sanan anima lyhenteenä) ja sopimuksenvaraiset merkit (esim. latinassa $=$ sanan esse lyhenteenä). ${ }^{3}$ Ryhmät ovat osittain päällekkäisiä, ja osa lyhennemerkeistä voidaan luokitella eri tavoin riippuen esiintymisyhteydestä. Esittelen eri lyhennetyyppejä ja niissä tavattavia merkintätapoja tarkemmin seuraavissa luvuissa.

\section{Suspensiot}

Termi suspensio(lyhenne) juontuu latinan verbistä suspendere 'to hang', 'riippua'. Suspensioista käytetään englanniksi myös nimitystä truncation, joka juontuu latinan verbistä truncare 'to cut off', 'leikata pois'. (Ks. esim. Dinkova-Bruun 2012: 1; Cappelli 1982 [1899]: 1; Lamberg 2009: 368-369.) Suspensioissa sanan lopusta

2. Käsikirjoituslitteraatioissa lyhenteiden avatut kohdat on yleensä merkitty joko kursiivilla tai alleviivaamalla. Tästä poiketen olen kursivoinut sekä aineistoni että latinan esimerkkien kielennäytteet mutta lihavoinut aukikirjoitetut kohdat, jotta ne erottuisivat muusta näytteestä. Aineistosta poimittujen kielenainesten kirjoitusasut olen pyrkinyt kirjoittamaan muuten aineistolähteiden kirjoitusasuja noudattaen, mutta lyhennemerkinnät olen siis avannut.

3. Lyhennemerkkiryhmien suomenkieliset nimet Lamberg 2009: 368-369. jätetään pois yksi tai useampia kirjaimia. Suspensiolyhentäminen voi olla kuitenkin myös syllabista, jolloin jätetään pois yksi tai useampi kirjain jokaisen tavun lopusta. Suspensioiksi luetaan myös sellaiset lyhenteet, jotka on muodostettu useammasta kuin yhdestä lopusta lyhennetystä sanasta (esim. latinan lyhenne $f q$ sanaliitosta filius quondam). (Cappelli mts. 4.)

Kuten edellä totesin, suspensioissa on usein jokin lyhentämistä osoittava merkki (Clemens \& Graham 2007: 90). Jotkin suspensioissa tavattavat lyhennemerkit ja merkintätavat voivat esiintyä myös kontraktioissa. Suspensioissa käytetään lisäksi joitakin erityisiä lyhennemerkkejä, jotka osoittavat, että sanan lopusta puuttuu kirjaimia, mutta jotka eivät ilmoita, mitä elementtejä lyhennetystä sanasta puuttuu. Yksi Cappellin esittelemä vain suspensioissa käytetty merkki on piste (esim. s.p.d. sanoista salutem plurimam dicit; ks. Cappelli 1982 [1899]: 2).

Aineistossani on useita erilaisia suspensioita, ja tavallisimmin ne on merkitty kaksoispisteellä tai sanan päälle merkityllä viivalla, joka voi suspensiossa olla joko yleinen lyhennemerkki tai $n$ - tai $m$-kirjaimen korvaava nasaalimerkki. Suspensio on voitu merkitä myös arabialaista numeroa 9 muistuttavalla pysyvämerkityksisellä merkillä (pysyvämerkityksisistä merkeistä tuonnempana). Nykykielen mukaista pistettä osoittamassa lyhentymistä tapaa harvoin. Hyvä näyte runsaasti erilaisia lyhenteitä sisältävästä tekstistä on Westhin koodeksin Litania (Westh $73 \mathrm{r}-75 \mathrm{~V}^{4}$ ). Siinä lyhenteillä on korvattu usein toistuvia sanoja ja fraaseja: Esimerkiksi armadha-sana esiintyy paitsi kokonaan kirjoitettuna myös asuissa Ar: ja Arma: Lauseke Laupias Herra Jumala on lyhennetty

4. Viittaan aineistolähteistä Kangasalan Missalen messuun digitoidun tiedoston sivunumeroinnilla ja muihin lähteisiin noudattaen lehtinumerointia, jossa lehden oikeaa eli recto-puolta osoittaa $r$ ja vasenta eli verso-puolta $v$. 


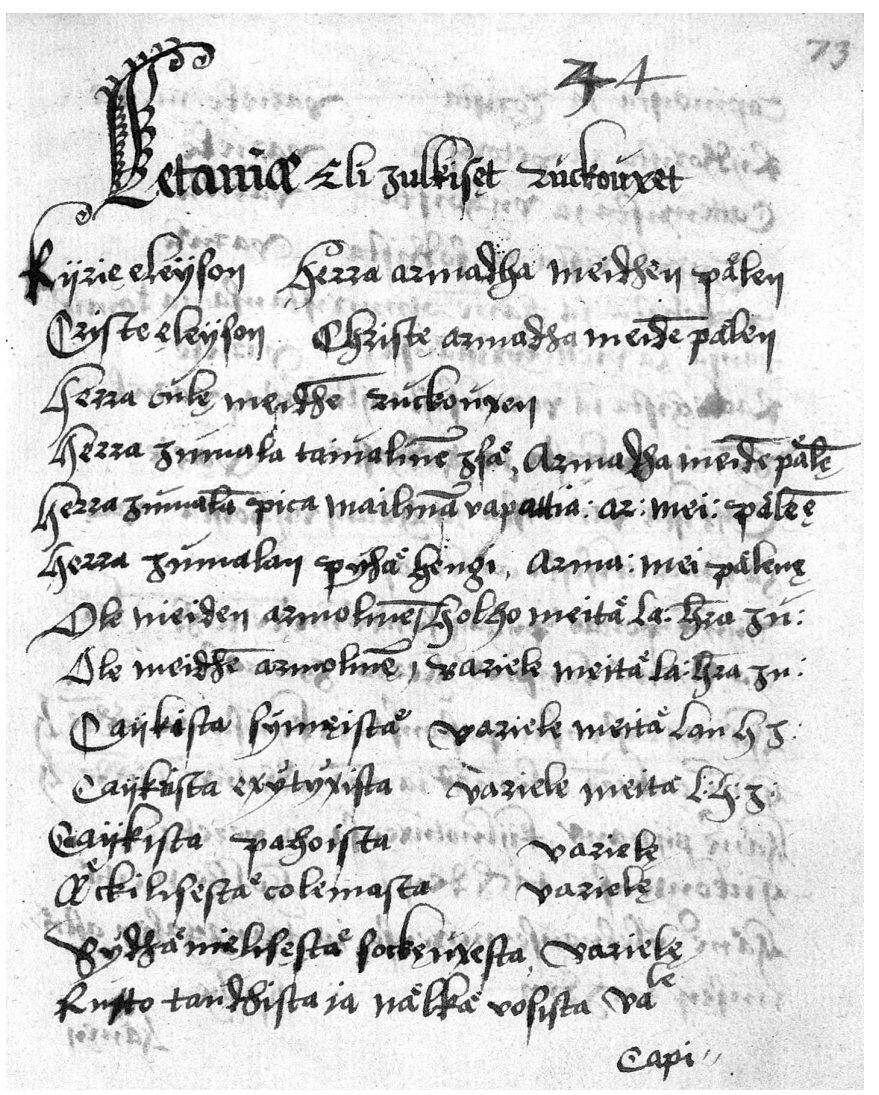

Kuva 1. Westhin koodeksin folio 73r, Litanian alku (Westh 73r).

esimerkiksi asuihin La. Hra Ju: ${ }^{5}$, Lau $H$ J: ja $L: H: J$ :. Suspensioiksi luettavat lyhenteet Cwle me:, Cwle ja $C$ tarkoittavat lauseketta Cule meitä Laupias Herra Jumala. (Ks. tark. Westh 73r-75v; ks. myös kuvaa 1.) Myös Uppsalan käsikirjan foliolla $89 \mathrm{r}$ (ks. kuvaa 2 s. 254) esiintyy suspensioita: $S$ : sanan Sanctus lyhenteenä (rivi 2) ja Capi: sanan Capitulumia lyhenteenä (rivi 5).

\section{Kontraktiot}

Termi kontraktio(lyhenne) juontuu sanasta contrahere 'to bring together', 'saat-

5. Lausekkeen Herra-sana on lyhennetty yleisenä lyhennemerkkinä käytetyllä koko sanan pituisella sananpäällisellä viivalla. taa yhteen'. (Dinkova-Bruun 2012: 1; Cappelli 1982 [1899]: 1; Lamberg 2009: 368-369.) Kontraktioissa sanaa on lyhennetty keskeltä niin, että mukana on ainakin sanan ensimmäinen ja viimeinen tai viimeiset kirjaimet, joskus myös niiden välissä olevia kirjaimia. Lyhenteet, joissa on vain ensimmäinen ja viimeinen kirjain, ovat niin sanottuja puhtaita kontraktioita; ne taas, joissa on kirjaimia keskeltä, ovat epäpuhtaita. Kuten suspensioissa kontraktioissakin on usein jokin lyhentämistä osoittava merkki. (Clemens \& Graham 2007: 89-90; Dinkova-Bruun 2012: 1.)

Latinankielisissä käsikirjoituksissa erityinen kontraktioiden ryhmä on nomina sacra 'pyhät nimet', jotka perustuvat 


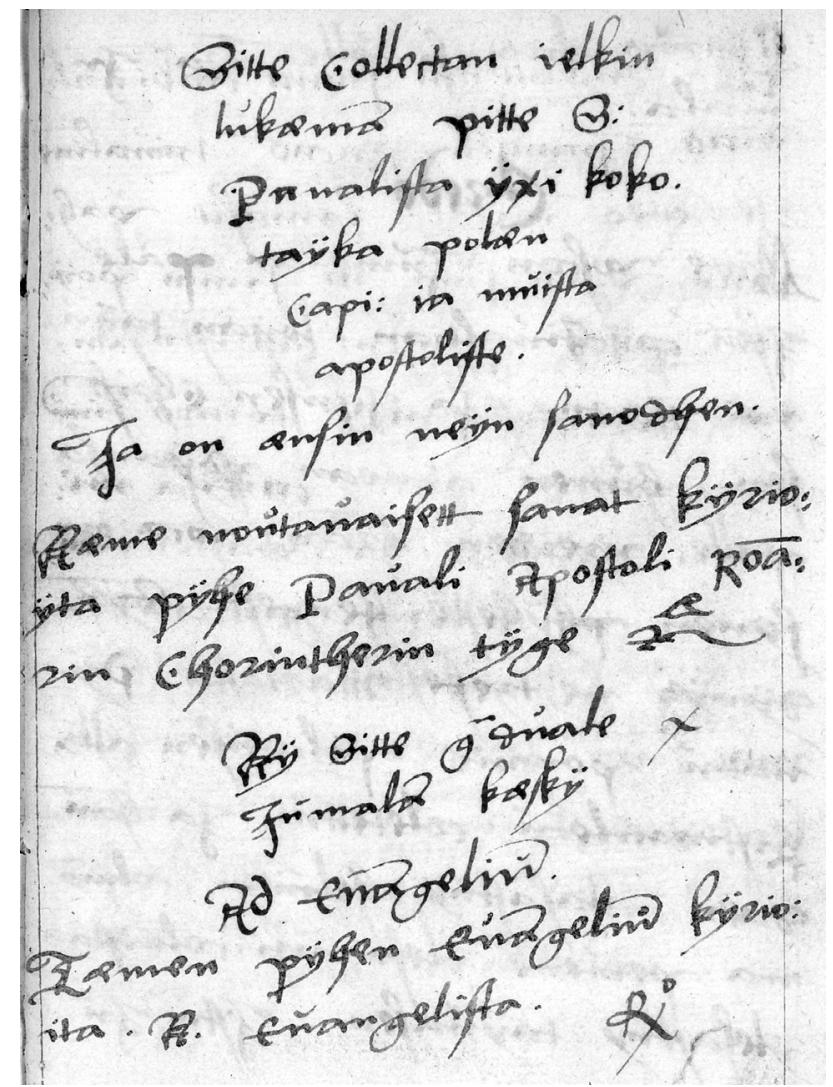

Kuva 2. Uppsalan käsikirjan folio 89r (UKK 89r).

kreikkalaiseen käytäntöön. Jotkin latinankieliset nimilyhenteet sisältävät myös kreikan kirjoitusmerkkejä, kuten Kristusta tarkoittava $x$ ps. (Clemens \& Graham 2007: 89.)

Aineistoni pyhissä nimissä esiintyy etenkin kontraktioita mutta myös suspensioita ja niin sanottua kontraktiosuspensiotyyppiä, jossa kirjaimia on poistettu sekä keskeltä että lopusta. Esimerkiksi Chre+lyhenneviiva tarkoittaa sanaa Christe (esim. Westh 125r, UKK 88r) ja Chus+lyhenneviiva sanaa Christus (esim. UKK 93r); Herra-sanan er on voitu merkitä lyhennemerkillä (esim. Westh $17 \mathrm{r}$ ja 134r) ja Jumala on usein kirjoitettu asussa $J u^{l a}$. Myös kreikkalaisia kirjoitusmerkkejä esiintyy joissakin Kristukseen viittaavissa lyhenteissä: esimerkiksi $X^{e}$ on Christe (esim. Westh 96v) ja $x 9$ on Christus (esim. Westh 118v ja 122r). ${ }^{6}$ Pyhien nimien lisäksi kontraktioita esiintyy muissakin sanoissa; muiden muassa sanansisäisen vokaalin kanssa esiintyvä $r$ tai pelkkä $r$ on voitu lyhentää. Esimerkiksi Uppsalan käsikirjan foliolla 1oor terueydhexi-sanassa ensimmäisen tavun er on merkitty lyhennemerkillä.

\section{Yleiset lyhennemerkit}

Yleisillä lyhennemerkeillä tarkoitetaan merkkejä, joita voidaan käyttää sekä kont-

6. Lyhenteissä $x$ on kreikan khii-kirjaimen merkkinä, mistä syystä olen avannut sanan ch-alkuisena. 
raktioissa että suspensioissa mutta jotka eivät kerro, miten sanaa on lyhennetty; ne toimivat vain yleisesti lyhentämisen osoittimina (Cappelli 1982 [1899]: 1). Yleisiä lyhennemerkkejä tunnetaan useanlaisia, mutta aineistossani esiintyy vain sanan päälle kirjoitettu vaakasuora viiva. Käsialasta riippuen viiva voi olla myös kaareva tai muistuttaa tildeä eli aaltoviivaa. Samaa merkkiä voidaan käyttää myös nasaalimerkkinä eli korvaamassa $n$ - tai $m$-kirjainta (ks. tark. seuraavaa lukua). Olen kuitenkin Cappellia (mt.) seuraten esitellyt kyseistä merkkiä eri ryhmissä ottaen huomioon sen monet funktiot. Suomenkielisessä tutkimuskirjallisuudessa merkistä on käytetty nimitystä nasaaliviiva harhaanjohtavasti silloinkin, kun se ei osoita nasaalin eli $n: n$ tai $m: n$ lyhentymistä (ks. esim. Rajamäki 2015: 29-30).

Aineistossani ulkoasultaan vaihteleva viiva esiintyy yleisenä lyhennemerkkinä Kangasalan missalen suomenkielisessä messussa, Westhin koodeksissa ja Uppsalan käsikirjassa. Kangasalan messussa viivalla on lyhennetty esimerkiksi $u$-kirjain sanassa hyuestisiugnasi (KMM 372). Alleluja-sanan lyhenteessä kirjainyhdistelmän alla päälle on merkitty kaksi lyhenneviivaa osoittamaan kahden eri kohdan lyhentämistä: alleluja (KMM 374). Kaisa Häkkinen ja Erkki Tuppurainen (2014: 2o) esittävät lyhennemerkinnän kaksinkertaisena ristinä ( $a$ 尘a) todeten, että sanasta on näkyvissä vain alku- ja loppukirjain. Häkkisen ja Tuppuraisen erikoisena esittelemä alleluja-sanan lyhenne on kuitenkin latinankielisten lyhentämiskäytänteiden perusteella tulkittavissa edellä esittämäkseni kirjainyhdistelmäksi kaksine lyhennemerkkeineen.

Westhin koodeksissakin alleluja-sana on lyhennetty yleisellä lyhenneviivalla mutta vain yksinkertaisella, jolloin sanassa tulkitaan olevan ainoastaan yksi lyhennemerkintä: alla+lyhenneviiva eli alleluja (Westh $17 \mathrm{v}$ ). Toisaalta yleinen lyhenneviiva esiintyy yksinään myös esimerkiksi Ewangelium-sanan lyhenteessä Ewanglm+lyhenneviiva, jossa se osoittaa kirjainten poistoa sekä l:n edeltä että jäljestä. Yksittäinen yleinen lyhenneviiva esiintyy myös esimerkiksi lyhenteessä Chrus+lyhenneviiva eli Christus (Westh 7or). Uppsalan käsikirjassa yleisellä lyhenneviivalla merkityiksi lyhenteiksi ovat tulkittavissa lähinnä useat herra-sanat, esim. Hran+lyhenneviiva eli Herran (UKK 96v).

\section{Pysyvämerkityksiset lyhennemerkit}

Pysyvämerkityksiset lyhennemerkit tarkoittavat aina samaa merkin asemasta riippumatta. Yleisin tällainen merkki on nasaalin merkkinä käytetty vaakasuora viiva tai pieni kaari tai lenkki. Suomenkielisten käsikirjoitusten tutkimuksessa käytetään yleensä termiä nasaaliviiva tai -merkki. Kyseessä on sama merkki kuin edellä esitelty yleisenä lyhennemerkkinä käytetty viiva. Vanhoissa suomenkielisissä teksteissä merkkiä käytetään yleisimmin osoittamassa nasaalin lyhenemistä. (Vrt. Cappelli 1982 [1899]: 13-14.)

Nasaalimerkillä lyhennettyjä kohtia on kaikissa aineistoni käsikirjoituksissa, niin suspensioissa kuin kontraktioissakin. Merkki on tavallisesti kirjoitettu sen kirjaimen tai tavun päälle, joka edeltää poistettua nasaalia, esimerkiksi ikänes+nasaaliviiva eli ikänens, sama+nasaaliviiva eli saman (KMM 370), nij+nasaaliviiva eli nijn, anname+nasaaliviiva eli annamme (Westh 33r), ana+nasaaliviiva eli anna, kuuliaine+nasaaliviiva eli kuuliainen (UKK 106r), heijttäkäme+nasaaliviiva eli heijttäkämme ja ottama+nasaaliviiva eli ottaman (UEK 3v ja 6r).

Toinen yleisesti esiintyvä pysyvämerkityksinen lyhennemerkki on arabialaista numeroa 9 tai suurta rivinylistä pilkkua muistuttava merkki, joka esiintyy latinassa $u s$-päätteen merkkinä (esim. prig 
eli prius).7 Latinassa merkki esiintyy usein rivinylisenä erotukseksi rivillä esiintyvästä numeroa 9 muistuttavasta merkistä, jota käytetään kirjainyhdistelmien con ja cum merkkinä. (Cappelli 1982 [1899]: 14-15.) Mainitunlainen merkki esiintyy Westhin koodeksissa ja Uppsalan käsikirjassa -us-lopun merkkinä riville kirjoitettuna: Christ9 eli Christus (Westh 116v), Jes9 eli Jesus (esim. UKK 93r) ja andexiandam9 eli andexiandamus (UKK 94r).

Cappelli esittää pysyvämerkityksisenä lyhennemerkkinä myös arabialaista numeroa 7 muistuttavan merkin, jolla voidaan korvata kirjainpari et tai yksinäis-e. Latinassa merkkiä käytetään sekä konjunktion et 'ja' merkkinä että osana pidempiä sanoja, joissa esiintyy yksinäis-e tai et-kirjainyhdistelmä. Latinan sanan et 'ja' ja fraasin et cetera 'ja niin edelleen' lyhenteitä Cappelli (1982 [1899]: 17; 1912: 408-409) esittelee myös sopimuksenvaraisten merkkien joukossa. Aineistossani arabialaista numeroa 7 muistuttava merkki esiintyy juuri latinan sanan et ja fraasin et cetera lyhenteenä. Esittelenkin näitä lyhenteitä tuonnempana sopimuksenvaraisten merkkien yhteydessä.

Kirjaimen $r$ sisältäviä tavuja on aineistossani lyhennetty aaltoviivalla, joka muistuttaa $n$ - tai $u$-kirjainta (vrt. Cappelli 1982 [1899]: 16). Tarkastelemissani teksteissä tällaisia lyhenteitä esiintyy usein sanoissa seurakunta ja sakramentti (ks. esim. Westh 52r; UKK 116r, 117r). Yksi tällainen niin sanottu $r$-lyhenne esiintyy Uppsalan käsikirjan foliolla 89r rivillä 11 (kuvassa 2): Graduale-sanan ra on merkitty aaltoviivalla. Vokaalin ja $r$ :n merkkinä aaltoviiva puolestaan on esimerkiksi Uppsalan käsikirjassa (98v) sanaparin Sancta marcus lyhenteessä, jossa Sanctasanan lyhenteenä on $S$. ja marcus-sanan lyhenteenä $m: n$, rivinylisen aaltoviivan, $c: n$ ja numeroa 9 muistuttavan mer-

7. Teknisistä syistä johtuen käytän lyhennemerkin tilalla numeroa 9. kin yhdistelmä. ${ }^{8}$ Samaa lyhennetyyppiä edustaa myös Westhin koodeksin foliolla 104r esiintyvä, tässä auki kirjoitettu paraxenna-sana. Häkkinen (toim. 2012: 150) avaa sanan asuun parhaxenna, mutta $h$ :ton tulkinta on lyhennetyypin kannalta oikeampi ja vanhassa kirjasuomessa mahdollinen. Vastaavaa asua tavataan myös lyhentämättömänä ainakin Uppsalan käsikirjassa (UKK 106r). Aaltoviivan lisäksi $r$ :n sisältäviä tavuja on aineistossani lyhennetty myös vaihtelevamerkityksisellä lyhennemerkillä, jonka esittelen seuraavassa luvussa.

\section{Vaihtelevamerkityksiset lyhennemerkit}

Vaihtelevamerkityksisten lyhennemerkkien tulkinta riippuu kontekstista. Aineistossani tällaisena lyhennemerkkinä esiintyy suora tai hieman kaareva viiva. Sitä käytetään myös yleisenä lyhennemerkkinä ja nasaalimerkkinä (ks. edellisiä lukuja), mutta merkitys vaihtelee silloin, kun se on $d: n, h: n$ tai l:n yläpidennyksen ${ }^{9}$ päällä tai kun se on $p: n$ tai $q$ :n yläpuolella tai niiden alapidennyksen päällä (Cappelli 1982 [1899]: 19-20). Näitä kaikkia latinassa tavattavia tapauksia ei esiinny aineistossani.

Viiva esiintyy aineistossani $h$ :n yläpidennyksen päällä ikään kuin jakaen yläpidennyksen kahtia ja osoittaen tavun her lyhentymistä Herra-sanassa (ks. esim.

8. Edellä esiteltyjen $r$-lyhenteiden aukikirjoittamiseen on tutkimuksissa sovellettu erilaisia käytäntöjä: Suomen kielen muistomerkkejä I -teoksessa kyseisiä kohtia on merkitty yläindeksiin eli päälinjan yläpuolelle kirjainten ylle kirjoitetulla r-kirjaimella (SKMI s. 76-77). Häkkinen (toim. 2012) on merkinnyt tällaisia lyhenteitä avatessaan $r: n$ kursiivilla.

9. Yläpidennys tarkoittaa pienaakkosen sitä osaa, joka nousee merkkien päälinjan yläpuolelle, alapidennys puolestaan sitä osaa, joka laskee peruslinjan alapuolelle. Kirjainten vartalo jää peruslinjan ja päälinjan väliin. (Ks. Tekstuaalitieteden sanasto s.v. alapidennys, peruslinja, päälinja, yläpidennys.) 


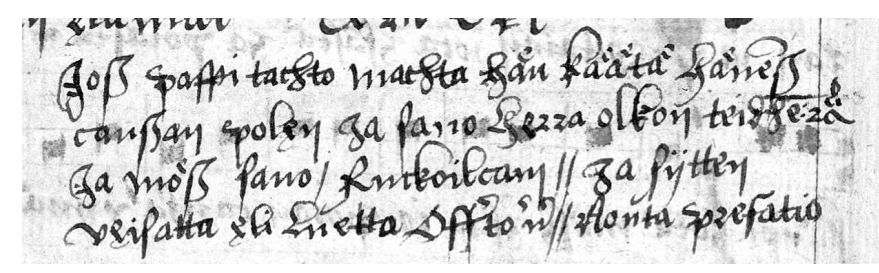

Kuva 3. Leike Westhin koodeksin foliosta 83v (Westh 83v).

KMM 367; Westh 3or, 32r). Myös Uppsalan käsikirjassa Herra-sana on usein lyhennetty viivalla, mutta viiva on koko sanan tai lähes koko sanan eikä vain $h$ kirjaimen päällä; täten viivan voi nähdäkseni tulkita ennemminkin yleiseksi lyhennemerkiksi (ks. esim. UKK 96v). Käytännössä Uppsalan käsikirjan Herrasanojen tulkinnassa on samantekevää, katsooko viivan yleiseksi vai vaihtelevamerkityksiseksi lyhennemerkiksi.

Aineistossani viiva esiintyy $p$-kirjaimen yhteydessä eri asemissa. $p$ :n alapidennyksen poikki menevä suora viiva osoittaa per-tavun lyhentymistä: esimerkiksi pkelen+viiva eli perkelen (Westh 101r), pkele+viiva eli perkele (UKK 95r). p:n alapidennyksen poikki menevä kaareva viiva, joka muodostaa lenkin alapidennyksen vasemmalle puolelle, osoittaa pro-tavun lyhentymistä: esimerkiksi ppheta+viiva eli propheta (Westh 116v). $p: n$ yläpuolelle kirjoitettu viiva puolestaan ilmaisee pre-tavun lyhentymistä: pfatio+viiva eli prefatio (UKK 92r). Aivan kuten latinankielisissä teksteissä viivaa käytetään aineistossani myös q:n alapidennyksen päällä osoittamassa quitavun lyhentymistä etenkin sanassa quin (esim. qn+viiva eli quin UKK 96v).

Vaihteleva merkitys on myös väärin päin olevaa kysymysmerkkiä tai pystyä $r$ kirjainta muistuttavalla merkillä. Merkki esiintyy lähinnä $r$-kirjaimen sisältävien tavujen lyhenteenä, ja se on toisinaan ajansäästämiseksi yhdistetty edeltävään kirjaimeen ohuella viivalla (ks. Derolez 2010:
83). Merkin kirjoittaminen kiinni edeltävään kirjaimeen nopeuttaa kirjoittamista, kun kynää ei tarvitse nostaa paperista. Edeltävän kirjaimen ja lyhennemerkin yhdistäminen ohuella viivalla on $r: n$ sisältävien tavujen lyhennyksistä levinnyt muiden peruslinjan yläpuolelle kirjoitettujen lyhennemerkkien yhteyteen. Niin kutsutuissa r-lyhenteissä edeltävän kirjaimen lopun ja lyhennemerkin yhdistämistä viivalla on käytetty alkuaan goottilaisessa kursiivikirjoituksessa, mistä se on levinnyt joihinkin muihin kirjoitustyyleihin. (Derolez 2010: 83-84; Bischoff 2013: 157.) Seuraavissa esimerkeissä on lyhennetty joko $r$ ja sitä seuraava tai edeltävä vokaali tai pelkkä $r$-kirjainta seuraava vokaali: suri (Westh 104r), peräti (Westh 105v), paremin (Westh 106r), Offertorium (Westh 83v; ks. kuvaa 3, rivi 4), Herra (Westh mm. 17r, $75 \mathrm{r}$ ja 134r), teruedhexi (UKK 10or). Joissakin lyhenteissä itse lyhennemerkki on sulautunut yhdistävään viivaan eikä erotu siitä. Lyhennetyn Offertorium-sanan loppunasaalin lyhennemerkki on kirjoitettu edeltävään kirjaimeen kiinni koukerolla, eikä tapaus juuri eroa niin sanotuista r-lyhenteistä. Lars Svenssonin (1974: 44) mukaan samantyyppistä koukeroa käytetään lyhennemerkkinä ruotsinkielisissä käsikirjoituksissa etenkin suspensioissa mutta myös kontraktioissa. Svenssonin esimerkit ovat kaikki sanoja, joissa lyhennettyyn kohtaan sisältyy $r$-kirjain.

Latinankielisissä teksteissä vaihteleva merkitys on myös lyhenteillä, joissa on piste yksittäisen kirjaimen molemmin 
puolin (Cappelli 1982 [1899]: 22). Aineistossani tällaisia lyhenteitä edustaa vain tapaus .N. Lyhenne esiintyy Uppsalan käsikirjan toimituskaavoissa niissä kohdin, joissa kuuluu mainita henkilön nimi. (Vrt. Cappelli 1912: 230.) Suvi Rajamäki (2015: liite 2, folio 89r) on Uppsalan käsikirjan messun aukikirjoituksessa merkinnyt lyhenteen niin, että ensimmäinen piste sijoittuu edeltävän sanan perään eikä osaksi lyhennettä. Teoksessa Suomen kielen muistomerkkejä I on Uppsalan käsikirjan pistelyhenteet tulkittu edellä esittämälläni tavalla; toisin sanoen pisteiden on nähty kuuluvan itse lyhenteeseen (SKMI s. $\mathrm{xx}$ ). Westhin koodeksissa on vastaavissa kohdin käytetty lyhennettä $N$ :, jossa kaksoispiste on suspensiolyhenteen merkki.

\section{Kirjainten ylle sijoitetut kirjaimet}

Kirjainten yläpuolelle eli yläindeksiin sijoitettuja kirjaimia osoittamassa sanan lyhentymistä esiintyy niin sanan keskellä kuin lopussakin. Sanan lopussa yläindeksiin sijoitetut kirjaimet, sekä konsonantit että vokaalit, osoittavat yleensä sanan loppua. Joitakin kirjaimia käytetään kuitenkin yläindeksissä ilmaisemassa sanan lyhentämistä jollakin tietyllä tavalla. Esimerkiksi vokaali konsonantin yläpuolelle kirjoitettuna edustaa kirjoitettua vokaalia ja $r$-kirjainta. (Cappelli 1982 [1899]: 30.) Aineistossani esiintyy ainoastaan sanan loppua osoittavia yläindeksiin sijoitettuja kirjaimia. Niissä lyhennetyt kohdat on täydennettävä kontekstin perusteella ilman lyhennetyypistä saatavaa vihjettä oikeasta tulkinnasta. Toisaalta tätä lyhennetyyppiä käytetään usein tiettyjen sanojen lyhentämiseen, esimerkiksi ju ${ }^{\text {la }}$ on jumala, $\sin ^{\mathrm{n}}$ on sinun. Yläindeksilyhenteitä esiintyy etenkin Westhin koodeksissa. Kuvassa 1 (s. 253) Westhin koodeksin foliolla $73 \mathrm{r}$ rivillä 15 on yksi yläindeksilyhenne: $v a^{l e}$ eli variele.

Westhin koodeksissa folion 109r toisella rivillä Kristusta tarkoittava lyhenne, jossa on yläindeksikirjoitusta, on käsialasta johtuen vaikeatulkintainen. Teoksessa Suomen kielen muistomerkkejä I (SKMI s. 138) lyhenne on asussa $C^{r}$ sen. Tällä kannalla näyttäisi aukikirjoituksen perusteella olevan myös Häkkinen (toim. 2012: 157): aukikirjoituksessa alkukirjain $C$ ja loppu-sen on jätetty kursivoimatta, eikä teoksessa ole kommentoitu kyseistä kohtaa kuten muita X:llä kirjoitettuja Kristukseen viittaavia sanoja. Alkuperäislähteessä on tulkintani mukaan kuitenkin $x$, yläindeksissä joko $v$ tai jokin muu kirjain ja sen-loppu. Jos yläindeksin kirjain on $v$, se on $u$ :n merkki. Joka tapauksessa lyhenteen ensimmäisen kirjaimen tulkintaa $x$ :ksi tukee sekä lähiympäristön $x$-kirjainten samankaltaisuus että nimen lyhentämisperinne. Nimen Christus lyhenteessä on yleisesti latinankielisissä teksteissä käytetty $x$-kirjainta, jonka käyttö juontuu nimen kreikankielisestä khii-kirjaimella alkavasta asusta X Westhin koodeksissa Kristus on muuallakin toisinaan kirjoitettu X:llä. (Vrt. lukuun Kontraktiot; Cappelli 1912: 401.)

Myös Uppsalan käsikirjassa esiintyy yläindeksilyhenteitä, esimerkiksi $i^{v}$ eli iesv (UKK 94r) ja ju $u^{\text {lata }}$ eli jumalata (UKK 114r). Uppsalan käsikirjassa on myös sellaisia yläindeksilyhenteitä, joissa yläindeksissä on lyhennemerkki ja nasaaliviiva, esimerkiksi Je $e^{\text {se+nasaaliviva }}$ eli Jesusen ja Ju ${ }^{\text {la+nasaaliviva }}$ eli Jumalan (esim. UKK 98v ja 99v). Näissä esimerkeissä nasaaliviivat osoittavat sanan taivutusmuotoa ja todellisia loppukirjaimia. Tulkitsen yläindeksilyhenteeksi myös folion 89r lopussa (ks. kuvaa 2 s. 254) esiintyvän lyhenteen, joka on aiemmissa litteraatioissa tulkittu etc.-lyhenteeksi (ks. SKMI s. 172; Rajamäki 2015: liite 2, litterointi 89r). Lyhenne on kirjoitettu punaisella musteella, jota on käytetty paikoin muuallakin käsikirjassa. Rajamäen (2015: 26) mukaan käsikirjan messussa on käytetty punaista mustetta kohdissa, joita ei ole ollut tarkoitus lausua ääneen. Nähdäkseni etc.-lyhennettä ei olisi tällaisessa koh- 
dassa merkitty punaisella musteella, sillä näin ei ole tehty esimerkiksi samalla sivulla aiemminkaan, vaikka lyhennettä ei ole tarkoitettu lausuttavaksi vaan korvattavaksi tilanteen mukaan asianmukaisella tekstillä. Todennäköisesti kyseessä onkin lyhenne, jossa on ison $R$-kirjaimen lisäksi lyhennemerkki ja yläindeksiin merkitty pieni $o$, mikä tarkoittaisi sanaa Responsio tai Responsorio (vrt. Cappelli 1912: 319; ks. myös Bischoff 2013: 168). Lyhenne selittyisi siis sillä, että raamatunlukua seuraava vastauslaulu on lehden verso-puolella mutta lehden recto-puolen lopussa on siitä ohje tai muistutus papille.

Kangasalan missalen messussa yläindeksilyhenteitä on vain muutama, esimerkiksi $s y n^{t}$ eli synnit (KMM 374) ja sijn $^{m}$ eli sijnum ${ }^{10}$ (KMM 376). Uppsalan evankeliumikirjan katkelmasta en tällaisia lyhenteitä ole löytänyt.

\section{Sopimuksenvaraiset merkit}

Sopimuksenvaraisia ovat sellaiset merkit, jotka eivät ole tunnistettavissa kirjaimiksi ja jotka esiintyvät yksinään ja edustavat tiettyjä yleisesti käytettyjä sanoja tai lauseita (Cappelli 1982 [1899]: 39). Cappellin esityksessä ryhmä on osittain päällekkäinen pysyvämerkityksisten merkkien ryhmän kanssa, sillä Cappelli esittelee muun muassa et-sanaa ja et cetera -fraasia tarkoittavia merkintöjä molemmissa ryhmissä. Clemens ja Graham (2007: 89) ovat luokitelleet tällaiset merkit symboleiksi. Heidän mukaansa symbolit ovat lyhennetyyppien kolmas ryhmä suspensioiden ja kontraktioiden ohella. Symbolit ovat merkkejä, jotka esiintyvät itsenäisinä ja tarkoittavat sanaa tai lausetta. Esimerkkinä mainitaan tironinen $e t$-sanaa tarkoittava merkki, joka muistuttaa arabialaista numeroa 7 tai $z$-kirjainta (vrt.

10. Käsikirjoituksessa on sanan $n$-kirjain merkitty $m$-kirjaimella, mutta sana luetaan kuitenkin $n$-loppuisena. ¿-merkkiin, joka on alkuaan $e: n$ ja $t: n$ ligatuuri eli yhteensulautuma).

Tutkimassani aineistossa sopimuksenvaraisia merkkejä edustavat lähinnä latinan sanaan et ja fraasiin et cetera viittaavat lyhenteet. Näistä et-sanan lyhenteitä aineistossani on vain muutamia, lähinnä Uppsalan evankeliumikirjassa, kun taas et cetera -fraasin lyhenteitä on eri lähteissä useita erilaisia. Edelliset on litteraatioissa yleensä avattu \&-merkillä ja jälkimmäiset etc.-lyhenteellä.

Uppsalan evankeliumikirjassa esiintyy numeroa 7 muistuttava tironisesta kirjoitustavasta juontuva et-merkki yhden kerran suomenkielisessä tekstissä rinnastuksessa veraita 7 mankäupi (lukuasu: vieraita et maankäypii) merkityksenään 'ja." Vastaava merkki esiintyy evankeliumikirjassa useissa latinankielisissä otsikoissa. Westhin koodeksissa merkki esiintyy kerran folion 66r marginaalissa Luukkaan evankeliumin lukuihin 12 ja 21 viittaavassa merkinnässä: Lu: $1272 i$ (Westh 66r marginaali; ks. myös Häkkinen toim. 2012: 110, alaviite 251).

Et cetera -fraasin lyhenteitä on aineistossani useita eri asuissa. Uppsalan käsikirjassa niitä on kahta eri tyyppiä (ks. UKK 87r ja 89r; jälkimmäinen kuvassa 2 rivin 10 lopussa s. 254), joista molemmista on hahmotettavissa tironinen $e t$-merkki, $c$ ja lopun lyhentämistä osoittava merkintä. Westhin koodeksissa vastaavia lyhenteitä on useita erilaisia, mikä johtuu siitä, että koodeksin laatimiseen osallistui useita eri kirjoittajia (esim. foliolla 83v, kuvassa 3 rivin 2 lopussa s. 257; ks. koodeksin eri käsialoista Kallio 2012: 26). Osassa Westhin koodeksin merkinnöistä tironinen etmerkki muistuttaa $z$-kirjainta tai kirjoittajan muualla tekstissä käyttämiä $r$-kirjaimia. Tironisen merkin rinnalla ja sijasta onkin yleisesti käytetty pyöreää $r$-kirjainta. Yhdessä tapauksessa et on kirjoitettu kirjaimin (Westh 108v). Useimmissa Westhin

11. Teknisistä syistä johtuen käytän tironisen et-merkin tilalla numeroa 7 . 
koodeksin merkinnöissä on hahmotettavissa sanaan cetera viittaava $c$, minkä lisäksi merkinnöissä esiintyy erilaisia lyhennemerkkejä. Kirjaimet ja merkit muodostavat lyhenteenä kuitenkin kiinteän kokonaisuuden, jonka purkaminen osiin ei välttämättä ole mahdollista eikä edes mielekästä. Todennäköisesti kirjoittajille on muotoutunut omanlaisiaan tapoja kirjoittaa tällaisia sopimuksenvaraisiksi merkeiksi ja symboleiksikin tulkittavia lyhenteitä.

\section{Lopuksi}

Vanhimpien suomenkielisten käsikirjoitusten lyhenteiden tarkastelu osoittaa, että varhaiseen kirjoitettuun suomen kieleen omaksutut lyhentämiskäytänteet juontuvat latinasta. Jotkin suomenkielisen tekstin keskellä olevista lyhenteistä voi tulkita latinankielisiksi. Tällaisia ovat etenkin symboleinakin pidettävät 'etc.'-merkinnät. Puhtaasti tai lähes puhtaasti latinaksi tulkittavien ilmausten lisäksi latinasta tutut lyhentämiskäytänteet ovat aineistossani käytössä myös omakielisissä ilmauksissa. Eri lyhentämistavat eivät ole suomenkielisissä teksteissä sidoksissa vain latinankielisiin tai latinasta lainattuihin sanoihin, vaan niitä on sovellettu laajasti eri sanojen lyhentämisessä. Aineistoni lyhenteissä on myös piirteitä, joita tavataan ruotsinkielisissäkin aikalaisteksteissä, mutta ruotsin vaikutteiden yksilöiminen vaatii vielä tarkempaa kartoitusta. Lyhenteitä esiintyy aineistossani sekä taajakäyttöisissä sanoissa että harvoin käytetyissä ilmauksissa (esim. quin ja peräti). Pyhissä nimissä eli Jumalaan ja Kristukseen viittaavissa sanoissa lyhenteitä tavataan usein.

Eri aineslähteissä eri lyhennetyyppejä esiintyy vaihtelevasti. Vanhimmaksi arvioitu Uppsalan evankeliumikirjan katkelma sisältää lähinnä nasaalilyhenteitä; Kangasalan missalen suomenkielisessä messussa lyhenteiden kirjo on vähän edellistä runsaampi. Uppsalan käsikirja, joka on lähteistäni toiseksi laajin mutta käsialaltaan yhtenäinen teos, sisältää monenlaisia lyhenteitä ja muista poiketen myös niin sanotusti kaksinkertaisia lyhenteitä, joissa yläindeksiin merkitty loppu on saanut päälleen lyhennemerkin. Westhin koodeksissa, joka sisältää useita eri käsialoja ja eri tekstejä tai tekstikokonaisuuksia, esiintyy eniten erilaisia lyhenteitä. Jo pelkällä koodeksin silmäilyllä voi havaita, että toisissa osissa lyhenteitä on runsaasti, toisissa ei juuri lainkaan. Joissakin aineiston teksteistä lyhenteitä on käytetty selvästi kirjoitusta nopeuttamaan. Muita havaittavia lyhentämisen funktioita ovat esimerkiksi tekstin silmäilyn ja seuraamisen helpottaminen sekä usein toistuvien kohtien ilmaiseminen lyhyemmin muun muassa tilan säästämiseksi. Tämän tutkimuksen puitteissa ei ole kuitenkaan ollut mahdollisuutta paneutua eri funktioihin tämän tarkemmin.

Tämä kirjoitus on avaus suomenkielisten käsikirjoitusten lyhenteiden tutkimukseen. Tulevan tutkimuksen vastattavaksi jää muun muassa se, miten lyhenteiden määrä ja laatu vaihtelevat eri käsikirjoituksissa ja eri käsialoilla kirjoitetuissa teksteissä sekä eri tekstilajeissa tai muuten funktioltaan erilaisissa käsikirjoituksissa. Kiinnostava jatkotutkimusaihe olisi myös se, voiko lyhenteiden käytöstä päätellä jotain pohjateksteistä. Tämän tutkimuksen aineisto-otos kattaa suppeahkon määrän pelkkiä uskonnollisia käsikirjoituksia, mutta näkökulmaa voisi laajentaa koskemaan myös esimerkiksi lakitekstejä ja painettua kirjallisuutta, joiden lyhenteitä on aiemmin esitelty vanhan kirjasuomen tutkimuksissa vain esimerkinomaisesti (ks. VVKS). Tällöin lyhenteiden käytön kokonaiskuva hahmottuisi entistä paremmin.

MARIA LEHTONEN
etunimi.sukunimi@kotus.fi

Kirjoittaja on Vanhan kirjasuomen sanakirjan toimittaja ja jatko-opiskelija Turun yliopiston suomen kielen oppiaineessa. 


\section{Aineistolähteet}

WESTH $=$ Westhin koodeksi. Helsinki, National Library, C.III.19. Codex Westh. www. codicesfennici.fi 11.8.2017).

$\mathrm{KMM}=$ Kangasalan missalen suomenkielinen messu $=$ Helsinki, National Museum of Finland. http://urn.fi/URN:NBN:fife201102171251.

$\mathrm{UKK}=$ Uppsalan käsikirja. Uppsala, Universitetsbibliotek, B 28. Magnus Eriksson's Landslag, Mikael Agricola's Manual. www.codicesfennici.fi. (11.8.2017.)

$\mathrm{UEK}=$ Uppsalan evankeliumikirjan katkelma. Uppsala, Universitetsbibliotek, T 387. Fragment of a Finnish Evangeliarum. Kirjoittajan hallussa olevat valokuvat: Maria Lehtonen. Myös www.codicesfennici.fi (11.8.2017).

Tammelan graduale. Åbo Akademin kirjaston Internet-sivut, Graduale Tammelense. http://bibbild.abo.fi/Tammela/graduale/ (11.8.2017).

Tukholman suomalaisen seurakunnan luterilaisen gradualen litteraatio $=$ artikkelissa HäKKINEN, KAISA - HANNIKAINEN, JORMA 2013: Tukholman suomalaisen seurakunnan luterilainen graduale. - Sananjalka 55 s. 100-127.

\section{Kirjallisuuslähteet}

Bischoff, BERNHARD 2013: Latin palaeography. Antiquity and the middle ages. Kääntäneet Dáibhí Ó Cróinín ja David Ganz. Cambridge: Cambridge University Press.

Cappelli, Adriano 1912: Dizionario di abbreviature Latini ed Italiani. Milano. http://www.hist.msu.ru/Departments/ Medieval/Cappelli/ (1.8.2017).

1982 [1899]: The elements of abbreviation in medieval Latin paleography. Kääntäneet David Heimann ja Richard Kay. University of Kansas Publications Library Series 47. Lawrence: University of Kansas Libraries. https:// kuscholarworks.ku.edu/bitstream/ handle/1808/1821/47cappelli.pdf (1.8.2017).

Clemens, Raymond - Graham, TimoTHY 2007: Introduction to manuscript studies. Ithaca: Cornell University Press.

Dinkova-Bruun, Greti 2012: Durham summer school in Latin palaeography. Opetusmonisteet 13.-24.8.2012 pidetyltä kurssilta.

Derolez, Albert 2003: The palaeography of gothic manuscript books from the twelfth to the early sixteenth century. Cambridge: Cambridge University Press.

Häkninen, Kaisa (toim.) 2012: Codex Westh. Westhin koodeksin tekstit. Wanhan suomen arkisto 5. Turku: Turun yliopisto, suomen kielen ja suomalaisugrilaisen kielentutkimuksen oppiaine.

HÄKKINEN, KAISA 2016: Uppsalan evankeliumikirjan katkelma, vanhin suomenkielinen käsikirjoitus. - Suomen kirkkohistoriallisen seuran vuosikirja 106 s. 138-165.

HäKKinen, KaISA - HANNiKAINEN, Jorma 2013: Tukholman suomalaisen seurakunnan luterilainen graduale. - Sananjalka 55 s. 100-127.

HäkKinen, Kaisa - Tuppurainen, ERKKI 2014: Kangasalan missalen suomenkielinen messu. - Sananjalka 56 s. 7-28.

KAllio, MARIA 2012: Westhin koodeksin kodikologiaa - Kaisa Häkkinen (toim.), Tutkimuksia Westhin koodeksista s. 1028. Turun yliopiston suomen kielen ja suomalais-ugrilaisen kielentutkimuksen oppiaineen julkaisuja 2. Turku: Turun yliopisto.

KO =KANKAANPÄ̈̈, SALLI - HEIKKilä, Elina - Korhonen, Rittta - MaAmies, Sari - Piehl, Aino (toim.) 2009: Kielitoimiston oikeinkirjoitusopas. 7., uudistettu ja korjattu painos. Kotimaisten kielten tutkimuskeskuksen julkaisuja 147. Helsinki: Kotimaisten kielten tutkimuskeskus. 
LAMBERG, MARKo 2009: Latinalainen paleografia. - Marko Lamberg, Anu Lahtinen \& Susanna Niiranen (toim.), Keskiajan avain s. 365-378. Suomalaisen Kirjallisuuden Seuran Toimituksia 1203. Helsinki: Suomalaisen Kirjallisuuden Seura.

RAJAмӓкі, SUvi 2015: Uppsalan käsikirjan messun piirteitä ja suhde muihin reformaatioajan messuteksteihin. Suomen kielen pro gradu -tutkielma. Turun yliopisto.

SKMI = Suomen kielen muistomerkkejä I. Monumenta linguae Fennicae 1. Mikael Agricolan Käsikirja ja Messu. Julkaisseet E. N. Setälä ja K. B. Wiklund. Suomalaisen Kirjallisuuden Seuran Toimituksia 82. Helsinki: Suomalaisen Kirjallisuuden Seura 1893.

Svensson, LaRs 1974: Nordisk paleografi. Handbok med transkriberade och kommenterade skriftprov. Lundastudier i Nordisk språkvetenskap. Serie A NR 28. Lund: Studentlitteratur. http://www.guide_specialsamlingar. ub.lu.se/bilder/svensson_paleografi.pdf Tekstuaalitieteiden sanasto $2010=\mathrm{HAL}-$ lamaA, Olli - Heikkilä, Tuomas Karhu, Hanna - Katajamäki, SAKari - Kokko, Ossi - Pulkkinen, Veijo: Tekstuaalitieteiden sanasto. Helsinki: Suomalaisen Kirjallisuuden Seura. http://www.edith.fi/tekstuaalitieteidensanasto/. URN:NBN:fi:sks-201010061001 (1.8.2017).

VVKS = Virtuaalinen vanha kirjasuomi -internetsivusto. http://www.helsinki.fi/ vvks/aanne-_ja_muoto-oppi/sanastosta/ index.html\#a-23.6 (23.3.2018).

Walta, Ville 2017a: Kuvailu lähteestä Uppsala, Universitetsbibliotek, B 28. Magnus Eriksson's Landslag, Mikael Agricola's Manual. http://www.codicesfennici.fi (11.8.2017).

— 2017b: Kuvailu lähteestä Uppsala, University Library, T 387. Fragment of a Finnish Evangeliarum. http://www. codicesfennici.fi (11.8.2017).

\section{Vanhaa kirjasuomea ongittelemaan}

Mitä tarkoittaa vanhan kirjasuomen sana one? Milloin sana paahtaa on tullut kirjakieleen? Entä millä sanalla vanhassa kirjasuomessa kutsutaan siiliä? Minkälaisia adjektiiveja tai yhdysverbejä vanhassa kirjasuomessa esiintyy? Näihin ja moniin muihin kysymyksiin löytyy vastaus Vanhan kirjasuomen sanakirjasta (VKS).
Vanhan kirjasuomen sanakirja on laaja tietopaketti kirjoitetun suomen kielen vanhimmasta sanastosta $1540-$ luvulta aina 180o-luvun ensimmäiselle vuosikymmenelle. Tätä kirjoittaessani sanakirjaa on julkaistu a:sta paistua-artikkeliin asti, yhteensä 39697 sana-artikkelia. Näistä päähakusana-artikkeleita on 29388 ; loput 